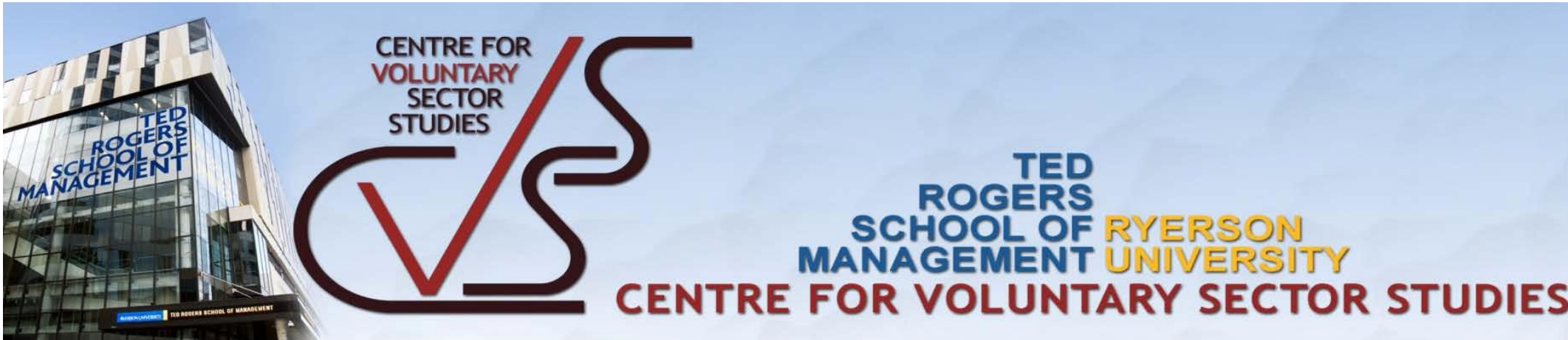

\title{
Charity Auctions on the Internet: An Exploratory Study ${ }^{1}$
}

\author{
Clare Chua and Ida Berger \\ Centre for Voluntary Sector Studies, Ryerson University
}

\section{Working Paper Series \\ Volume 2006 (2)}

\author{
350 Victoria Street \\ Toronto, Ontario, M5B 2K3 \\ Tel: (416) 979-5000 x 6739 / Fax: (416) 979-5124 \\ cvss@ryerson.Ca \\ http://www.ryerson.ca/cvss/working_papers/
}

\footnotetext{
${ }^{1}$ The authors gratefully acknowledge the Office of Research Services, SIG fund, at Ryerson University for financially supporting this project, Professor Agnes Meinhard for her valuable comments on an earlier version of this manuscript, Itay Greenspan for the literature search and Michael Eng for assisting in data collection and literature search.
} 
The purpose of this study is to explore the value of conducting auctions on-line as a method of raising funds for charity organizations. We review the relevant literature on auctions, in both on-line and live formats and find that there remain numerous unanswered questions for charities considering this funding mechanism. In this exploratory study we collect and compare bid and selling information from eBay's standard and charity sites and conclude, surprisingly, that the auction clearing prices for comparable items are higher on the non-charity site.

\section{Introduction}

Sale of goods through open-bid auctions in auction houses has been a popular market of exchange for hundreds of years. The strong emergence of the Internet and its growing presence in our daily lives now includes auction based exchanges. Everyone has heard of eBay, the premier internet auction web site. Among other popular auction web sites are uBid, Yahoo! Auctions and Bidz. The surge of auctions on the Internet in recent years has uncovered new issues and new challenges in the study of auction behavior (Ariely et. al.,2002; Chakravarti et. al., 2002; Lucking-Reiley, 1999; Roth \& Ockenfels, 2002). Furthermore, the popularity of these auction sites has recently attracted the attention of charity organizations interested in maximizing the funds they raise with the growing use of on-line auctions by charitable organizations creating a new domain for academic and applied research. An extensive search on the World Wide Web showed a rapidly growing use of online-auctions by non-profit organizations as a new fundraising tool, with eBay Charity Auctions (http://www.givespot.com/shop/charityauctions.htm) claiming to have raised more than $\$ 3$ million. The purpose of this study is to determine whether charity organizations can raise more money using charity specific sites vs. non-specific sites. In traditional auction settings where the bidders gather in a room to bid for an item, Engers and McManus ( 2002 ) found that charity auctions raise more money than non-charity auctions. In this paper we test their hypothesis in the online auction setting. In this exploratory study we compare the exchange prices of similar items on eBay's charity and standard auction sites.

\section{Context}

Online auctions have become one of the hottest phenomena on the worldwideweb since their introduction in 1995. They give buyers a virtual marketplace with a countless array of merchandise, and they give sellers a virtual 'storefront' where they can offer for sale almost everything in a spatially limitless market. Online auctions are virtual marketplaces that allow the sellers and bidders separated in space to transact in real time.

eBay is the industry leader with over 4 million listings (http://auctions.nettop20.com/) and has been rated the most popular in various online sources such as auctions.nettop20.com/, $\quad$ freecallstousa.com/greatauction,

http://weblinks.searchwho.com/search/greatwebsites/gwscat4.html. eBay was founded in 1995 and operates an Internet-based service environment facilitating exchanges between registered buyers and sellers. eBay now offers a wide spectrum of product categories ranging from Antiques and Arts to Electronics including speciality categories such as properties, motors, and also major regional sites in countries like Canada, UK and Australia. 
On eBay, the bidding for each auction closes at a scheduled time with the highest bidder winning the item, but not necessarily paying the highest amount offered. Sometimes the winner pays the second highest offer. This is so because the bidder is asked to register a bid that reflects the highest amount he/she is willing to pay. As bidding proceeds the system automatically increments the bid amount up to his/her maximum amount but only so high as is necessary to be the highest actual bid. In some cases sellers set a 'reserve price,' which is the lowest price they will accept and some sites disclose this reserve price during the auction, while others do not. If no one bids at or above the reserve price, the auction will close without a winner. At the close of a successful auction, the buyer and seller communicate to arrange for payment and delivery of the item(s), usually by email. Two things are particularly interesting about this structure. First, the selling or winning price mechanism is closer to a "second price" price structure than the classic first price structure. Note, under a 'first price' auction the highest bidder wins the item and pays the highest bid price. Under a 'second price' auction the highest bidder wins the item but pays the second highest bid price. Under a 'third price' auction the highest bidder wins the item but pays the third highest bid price.

Online charity auctions are similar to "regular" online auctions with the difference that all items on the charity site are offered by either registered charities or other registered not-for-profit organizations. For buyers the main difference is that the revenues go to support not-for-profit organizations. For the sellers, in this case the non-profit organizations, the key difference between online charity auctions and the "regular" online auctions is that eBay hosts the auction for free. In other words, for non-profit organizations, eBay waives its standard $2.5 \%$ commission.

\section{Background of auctions in virtual space}

A substantial amount of theoretical and empirical work has been done on auctions, due in part to their popularity as an exchange mechanism that bypasses market intermediaries, and in part to their theoretical and empirical significance (Kagel ,1995; Klemperer ,1999). The main focus of experimental work on independent private value single-unit auctions has been the testing of the Revenue Equivalence Theorem (Vickrey, 1961). The theorem states that when bidders are risk-neutral, the expected revenue for the seller is the same for the four classes of auctions: firstand second-price sealed-bid auctions ${ }^{2}$, English ${ }^{3}$ and Dutch $^{4}$ open bid auctions. However, most empirical tests of the theorem do not support this proposition. Instead, it has been shown that the winning bid price in first-price sealed-bid auctions are generally higher than the theoretically proposed risk neutral equilibrium bids. Risk aversion has been proposed to explain this deviation (Smith, 1967; Belovicz , 1979; Cox, Roberson and Smith , 1982; Cox, Roberson and Smith, 1983; Cox, Roberson and Smith , 1985a; Hansen, 1985; Kagel and Levin, 1985; Miller and Plott, 1985; Hansen, 1986; Forsythe, Isaac and Palfrey, 1989; Harrison ,1989; and Kagel and Levin, 1993). The theoretically contradicting results have generated a stream of work focused on bidders' risk preferences, attitudes and profiles (Cox, Smith and Walker, 1985b; Harrison, 1990; Rietz, 1993).

Research now indicates that selling prices, and therefore seller revenue, vary as a function of the value structure of auction bidders, the risk preferences of the bidders and the pricing structure of the auction. Results of experiments comparing the seller's expected revenue for first-, second- and third-price sealed-bid regular auctions indicate that when the bidders are risk seekers (vs. risk averse), and homogeneous (vs. heterogeneous) in terms of risk profile, a 'third price' structure yields the highest (vs. the lowest) expected revenue for the seller, regardless of item valuations. When, on the other hand, the bidders are heterogeneous in terms of risk profile, the expected revenue from a first-price structure is highest (vs. lowest) among all three auction types, so long as the valuations of the bidding objects are relatively high (vs. low) (Lim, Lee, Chua, 2003). 
While there is a rich body of literature in auction theory, an extensive search found no academic studies on on-line charity auctions. However, issues of on-line charity auction management have been raised by nonprofit organizations, perhaps as a result of its growing usage (http://www.nonprofits.org/npofaq/16/05.html). While many benefits have been highlighted (such as geographic reach), managers remain unclear as to whether on-line auctions generate as much, or perhaps more funds compared to traditional live auctions, or other fundraising methods. Furthermore, the more complex question from the fund raiser's perspective of which auction mechanism, donor risk profile and item value combination will raise the most money in an online charity auction has not been explored.

The charity situation represents a completely different motivational context relative to a standard acquisition situation. If bidders in a charity situation are buying out of altruistic motives, and are thereby willing to accept more risk, or are less sensitive to product or purchase risk (that is are greater risk seekers) then according to previous results, the third price structure should yield the highest revenues for the charity. From a practical/applied perspective, understanding how to generate the highest revenue for the charity is an important, real, contribution. Nonprofit organizations are under tremendous funding pressures and tremendous pressures to manage their activities in a more professional and business like fashion (Meinhard and Foster, 2000). Indeed, according to the deputy director of the National Committee for Responsive Philanthropy, "philanthropy and the entire nonprofit sector face more challenges than at any time in recent memory" (Conlin et. al., 2004). In this revenue stressed environment, the on-line auction is becoming more and more popular among fund-raisers. However, it is being used in a rather 'blind', uninformed fashion. Little, if any attention has been paid to whether or not revenues could be improved through judicious structural decisions, such as the price paid mechanism given the valuation, risk profile of the auction.

While there does appear to be considerable empirical research about on-line auction management, little of this research speaks directly to the charity organization's issues. For instance, Hou and Rego ( 2003 ) identified four types of bidders, namely, goal-driven bidders, experiential bidders, playful bidders, and opportunistic bidders. The opportunistic bidders on average pay the lowest price. The goal-driven bidders are most likely to be winners. The experiential bidders on average pay the highest price due to their lack of experience. The playful bidders enjoy bidding online and because of their concentration on a single auction, they also pay a relatively low price. Similarly, Wilcox ( 2000 ) provided three interesting conclusions regarding the ability of auction theory to describe consumer behaviour. First, when strategic dominance is strong, more experienced bidders are more likely than less experienced bidders to follow Nash equilibrium bidding strategies. Second, when strategic dominance is weak, experience has a weaker impact on behaviour. Finally, the results also point to the conclusion that most non-

\footnotetext{
${ }^{2}$ Note, under a 'first price' auction the highest bidder wins the item and pays the highest bid price. Under a
} 'second price' auction the highest bidder wins the item but pays the second highest bid price.

${ }^{3}$ The English auction is similar to the open-outcry auction or the ascending-price auction. It is used commonly to sell art, wine and numerous other goods

\footnotetext{
${ }^{4}$ In a Dutch auction (also known as descending-price auction), the bidders start bidding at a very high price, and the price is progressively lowered until a bidder chooses to accept the current price. The winner pays that price for the item.
} 
professional bidders do not bid in a manner consistent with game-theoretic predictions. Clearly, experience, motivation and other consumer characteristics influence on-line charity behaviour and results, however, there is no information as to the likely profile of bidders on charity auction sites.

Research points to the fact that factors under the control of the seller also matter. Bapna ( 2003 ) for instance also identified three different bidding strategies employed by consumers and also considered a number of control factors that are available to online auctioneers. He found that the bid increment is not only the single most important control factor, but also that it influenced consumer bid strategies. Beam and Segev ( 1998 ) also looked at seller control strategies and grouped sellers into two categories, namely, mainliners (who have online auctions as their main line of business) and sideliners (who are existing auction houses, which have recently ventured onto the Internet. They found not only that the mainliners tend to have nicer auction sites but they are also more likely to "do it right" more frequently than the sideliners, possibly indicating a new set of core competencies for online auctioning which is separate from both auctioning in general and from Internet companies. Once again, it is not clear what "doing it right" might mean in a charity context. Clearly, charity organizations are neither mainliners nor sideliners.

In the live charity auction domain, Carpenter, Holmes and Matthews ( 2005 ) found only limited support for the standard models of charity auctions offered by Engers and McManus (2002) and Goeree et al. (2004) and their field results are contrary to those generated in the lab with induced altruistic preferences (e.g., Goeree and Schram, 2003). Instead of generating the most revenue, both the all-pay and the second price auctions were revenue dominated by the first price auction. Not only were these results contrary to theoretical predictions, they were also contrary to laboratory results. The authors explained their results in terms of consumers' lack of experience with the second price and all-pay structures. No research has been conducted in an online charity auction context. Clearly there is a need to understand the online charity auction situation both in terms of bidder characteristics and seller control factors.

\section{Methodology}

In an attempt to explore the on-line charity domain we collected data from eBay.com's non-charity and charity auction sites (www.eBay.com). We conducted two exploratory studies. In the first study, we randomly selected items being traded in 14 general categories and we called this the between categories study (study 1). There are a total of 34 categories as of 20 September,2005 (see Table 1). There are sub-categories within each category. For example, the sub-categories for 'Cell Phones' are accessories parts, phones only, prepaid phones and cards, phones with new plan purchase, etc. The sub-categories are further categorized. For example, the subcategory of "Accessories parts (of "cell phone" category) is further divided into antennas, batteries, cars kits \& car charges.

The technique of sampling the 14 categories are based on a random process as well as based on the availability of information on the closing bid which will give us the winning bid price and number of bid for each item.

The data collection period began on 20 September, 2005 and continued until 20 December, 2005. During this collection period, we encountered difficulties finding categories with enough number of auctions taken place (i.e. item successfully closed with a winner paying for the item) and with similar item's value. 
Table 1: eBay Categories

\begin{tabular}{|c|l|}
\hline eBay Categories* & \multicolumn{1}{|c|}{$\begin{array}{c}\text { Categories considered in } \\
\text { our studies }\end{array}$} \\
\hline Antiques & Camera - 35MM SLR \\
\hline Art & Cell Phones \\
\hline Baby & $\begin{array}{l}\text { Computers - Used Hard } \\
\text { Drives }\end{array}$ \\
\hline Books & $\begin{array}{l}\text { Computers - Laser Colour } \\
\text { Toner }\end{array}$ \\
\hline Business \& Industrial & Electronics - MP3 Players \\
\hline Cameras \& Photo & Dolls - Felicity-Samantha \\
\hline Cars, Parts \& Vehicles & DVDs \\
\hline Cell Phones & Gift Certificates - \$100 Value \\
\hline Clothing, Shoes, \& & Video Games - Sony PSP \\
\hline
\end{tabular}

\begin{tabular}{|c|l|}
\hline Accessories & \\
\hline Coins & Musical Instruments \\
\hline Collectibles & Musical Instruments - Guitars \\
\hline Computers \& & Music - Reel Tapes \\
\hline Consumer Electronics & Music - CD Box Sets \\
\hline Crafts & Home \& Garden Candles \\
\hline Dolls \& Bears & \\
\hline DVDs \& Movies & \\
\hline Entertainment & \\
Memorabilia & \\
\hline Gift Certificate & \\
\hline Health \& Beauty & \\
\hline Home \& Garden & \\
\hline Jewellery \& Watches & \\
\hline Music & \\
\hline Musical Instruments & \\
\hline Pottery \& Glass & \\
\hline Real Estate & \\
\hline Specialty Services & \\
\hline Sporting Goods & \\
\hline Sports Mem, Cards and & \\
Fan Shop & \\
\hline Stamps & \\
\hline Tickets & \\
\hline Toys \& Hobbies & \\
\hline Travel & \\
\hline Video Games & \\
\hline Everything Else & \\
\hline
\end{tabular}

Source from www.eBay.com 
In study one there was great variety within each category possibly compromising the comparisons of selling price. In particular, there may have been considerable variation in the value of the products grouped into each of our categories. Consequently, for study two we selected similar items within each category and grouped the items auctioned into specific item categories with greater similarity of characteristics, i.e. same products with essentially the same or very similar valuations. Most of the products were nearly identical.

\section{Findings}

Study One: Among the 14 categories in study one, we found that only one category (computers- Used Hard drivers) has a mean bid price higher in the charity auctions than in the non-charity auctions, $\mathrm{p}<0.01$ (see Table 2 ). This does not seem to support our hypothesis. Three out of the 14 categories have mean bid prices that are higher in the non-charity auctions than in the charity auction $(\mathrm{p}<0.05)$. These three categories are- 'Dolls - Felicity-Samantha', 'Home \& Garden Candles' and 'Musical Instruments'. Importantly, the price differential in these cases ranged from as low as $14 \%$ for 'home and garden candles' to as high as $57 \%$ for the 'musical instruments - guitars'. Our expectation that because of altruistic motives the charity sites would yield higher revenues was not supported. Given that the price differential was considerably greater than the $2.5 \%$ savings in administration costs provided by eBay to the charities, it appears that the charities would have reaped higher revenues had they offered their items on the standard, non-charity sites. 
Table 2: Study 1: Between Category Comparisons

\begin{tabular}{|c|c|c|c|c|c|c|c|c|c|c|c|}
\hline Category Name & & Non & -Charity Au & tions & & & Cha & y Aucti & & & \\
\hline & $\begin{array}{l}\text { Min } \\
\text { Price }(\$)\end{array}$ & $\begin{array}{l}\text { Max Price } \\
(\$)\end{array}$ & Mean Bids & $\begin{array}{l}\text { Mean Price } \\
(\$)\end{array}$ & Std Dev. & $\begin{array}{l}\text { Min } \\
\text { Price }(\$)\end{array}$ & $\begin{array}{l}\text { Max } \\
\text { Price }(\$)\end{array}$ & $\begin{array}{l}\text { Mean } \\
\text { Bids }\end{array}$ & $\begin{array}{l}\text { Mean } \\
\text { Price } \\
(\$)\end{array}$ & Std Dev & $\begin{array}{l}\text { Size } \\
\text { Effect }\end{array}$ \\
\hline Camera - 35MM SLR & 6 & 125 & 6.44 & 49 & 25.94 & 10 & 152 & 11.5 & 50 & 28.08 & 0.05 \\
\hline Cell Phones & 31 & 244 & 14.24 & 151 & 58.39 & 61 & 199 & 17.56 & 145 & 50.66 & -0.15 \\
\hline 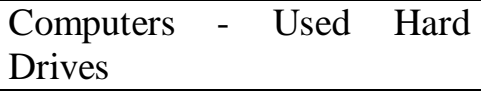 & 2 & 28 & 4.36 & 11 & 8.01 & 1 & 21 & 4.7 & 10 & 6.68 & -0.14 \\
\hline $\begin{array}{l}\text { Computers - Laser Colour } \\
\text { Toner }\end{array}$ & 15 & 50 & 7.66 & 34 & 10.34 & 48 & 61 & 14.13 & 55 & 5.09 & $3.51 *$ \\
\hline Electronics - MP3 Players & 123 & 400 & 25.05 & 243 & 72.46 & 168 & 345 & 21.38 & 221 & 54.88 & -0.48 \\
\hline Dolls - Felicity-Samantha & 301 & 135 & 14.76 & 80 & 20.72 & 43 & 94 & 14.27 & 68 & 14.31 & $-1.00 *$ \\
\hline DVDs & 19 & 280 & 14.06 & 90 & 64.28 & 31 & 193 & 12.88 & 96 & 51.51 & 0.16 \\
\hline Gift Certificates - \$100 Value & 39 & 100 & 12.88 & 70 & 20.1 & 39 & 112 & 11.6 & 70 & 21.8 & -0.01 \\
\hline Video Games - Sony PSP & 210 & 243 & 27.17 & 226 & 12.79 & 215 & 265 & 28.75 & 238 & 20.71 & 0.95 \\
\hline Musical Instruments & 20 & 766 & 8.9 & 97 & 106.78 & 10 & 565 & 9.72 & 78 & 87.63 & -0.28 \\
\hline Musical Instruments - Guitars & 16 & 472 & 7.7 & 102 & 96.7 & 10 & 185 & 9.93 & 65 & 51.86 & $-0.69 *$ \\
\hline Music - Reel Tapes & 1 & 37 & 2.52 & 12 & 9.55 & 10 & 41 & 2.27 & 16 & 10.75 & 0.57 \\
\hline Music - CD Box Sets & 13 & 59 & 7.14 & 36 & 12.79 & 20 & 60 & 7.11 & 39 & 14.03 & 0.23 \\
\hline Home \& Garden Candles & 4 & 44 & 3.38 & 16 & 7.47 & 7 & 31 & 9.66 & 14 & 4.88 & $\overline{-} \overline{4} * * *$ \\
\hline
\end{tabular}

Note: * significant at $\mathrm{p}<0.01 ; * *$ significant at $\mathrm{p}<0.05$

We computed the Cohen'd as the size effect. 
Study two: Because we were concerned that our groupings were not sufficiently detailed, in the second study we controlled for the valuation of the items and compared the mean prices of the same products offered on eBay's charity and non-charity sites. We found that out of 11 products we observed, 8 products have significant evidence to indicate that the mean prices were different in the two charity situations.

Table 3: Study 2 Within category comparisons

\begin{tabular}{|l|c|c|c|c|c|}
\hline \multirow{2}{*}{ Product } & \multicolumn{2}{|c|}{ Non-Charity } & \multicolumn{2}{c|}{ Charity } & \multirow{2}{*}{ pvalue } \\
\cline { 2 - 5 } & $\begin{array}{c}\text { Mean } \\
\text { Bids }\end{array}$ & $\begin{array}{c}\text { Mean Price } \\
(\$)\end{array}$ & Mean Bids & $\begin{array}{c}\text { Mean Price } \\
(\$)\end{array}$ & \\
\hline $\begin{array}{l}\text { SVP Digital } \\
\text { Camera Model } \\
\text { \#1530 }\end{array}$ & 25.63 & $\mathbf{1 5 0}$ & 26.33 & 135 & $\mathbf{0 . 0 1}$ \\
\hline $\begin{array}{l}\text { SVP Digital } \\
\text { Camera Model } \\
\text { \#6030 }\end{array}$ & 27.55 & $\mathbf{1 1 8}$ & 24.63 & 108 & $\mathbf{0 . 0 7}$ \\
\hline $\begin{array}{l}\text { SVP Digital } \\
\text { Camera Model } \\
\text { \#7515 }\end{array}$ & 30.25 & $\mathbf{1 5 1}$ & 29.80 & 136 & $\mathbf{0 . 0 0}$ \\
\hline $\begin{array}{l}\text { SVP Digital } \\
\text { Camera Model } \\
\text { \#7530 }\end{array}$ & 24.67 & 145 & 26.67 & 139 & 0.27 \\
\hline $\begin{array}{l}\text { SVP Digital } \\
\text { Camera Model } \\
\text { \#12P }\end{array}$ & 25.76 & 126 & 28.36 & $\mathbf{1 5 1}$ & $\mathbf{0 . 0 1}$ \\
\hline $\begin{array}{l}\text { SVP Digital } \\
\text { Camera Model } \\
\text { \#12X }\end{array}$ & 31.71 & 158 & 29.92 & 146 & 0.13 \\
\hline iPod Nano* & 22.51 & $\mathbf{2 3 1}$ & 17.75 & 195 & $\mathbf{0 . 0 0}$ \\
\hline Board Games & 6.79 & 22 & 14.27 & $\mathbf{3 2}$ & $\mathbf{0 . 0 7}$ \\
\hline Barbie Dolls & 5.56 & 16 & 7.52 & 18 & 0.28 \\
\hline Xbox Platinum & 19.68 & 599 & 26.47 & $\mathbf{7 0 2}$ & $\mathbf{0 . 0 0}$ \\
\hline $\begin{array}{l}\text { Xbox Platinum } \\
\text { with Games }\end{array}$ & 32.2 & $\mathbf{7 9 2}$ & 20.25 & 701 & $\mathbf{0 . 0 2}$ \\
\hline Not & & & & & \\
\hline
\end{tabular}

Note: *Insufficient Data

Comments

- A large number of auctions went unsold in both non-charity and charity formats.

- The comparisons were between same or similar products. With charity auctions, it is usually the one-of-a-kind items that are listed (e.g. autographed memorabilia). These auctions tend to chase a high number of bidders and closing values. Data for charity products which were regular retail products was hard to come by.

Five of the eight significant differences occurred with the mean prices higher in the noncharity auction situation $(\mathrm{p}<0.10)$. Three of the eight differences had mean prices higher in the charity 
situation. Also important is the finding that the percentage differences in prices paid were substantial. When the non-charity site had higher prices the differences ranged from a low of $9 \%$ to a high of $18 \%$. The price premium when the charity site price was higher ranged from a low of $17 \%$ to a high of $46 \%$ in the board game group. Overall, once again, the results do not support our belief that in general charity auction sites would raise more money than the non-charity sites.

\section{Conclusions}

The data collected from the eBay auction sites does not seem to support our belief that charity auction sites would raise more money than the non-charity auction sites. In fact, the results imply that charities would be better off and would raise more money for their cause if they were to offer their items on the standard on-line auction sites, even if they must thereby pay the $2.5 \%$ hosting fee.

The results support the need to more clearly understand whether or not bidding behaviour and revenue results vary as a function of the profit categorization of the seller. That is, there is a need for more knowledge and therefore more research that compares on-line charity auctions to non-charity auctions. What is needed is a better understanding of the particular bidder characteristics and seller control factors that would maximize revenues for charity sellers. One place to begin would be to examine the impact of the auction mechanism on the fund raiser's revenue under two conditions, namely, when the bidders have homogeneous risk attitudes (subjects of similar risk profile bidding together) and when the bidders' risk preference is heterogeneous (subjects of varying risk attitudes bidding together). The results of this kind of work would provide a rich body of information for academics interested in charity theory and importantly would help non-profit organizations develop more successful strategies to maximize revenues.

Our findings suggest interesting discussions as to why the clearing prices are not higher in the charity auction situation. Perhaps the profile of bidders, for example, their inexperience may contribute to the bidding results. Or perhaps, charity auctions need to consider a different auction format. eBay uses the same auction mechanism for the charity and non-charity sites, but this may be disadvantageous for charity sellers. While it may still be the case that on-line auctions are a cost effective way for charities to raise needed funds, we need greater understanding of the portability of the standard online auction structure for the charity context.

\section{References}

Ariely, D., Itamar, S. (2002). "Buying, Bidding, Playing or Competing? Value Assessment and Decision Dynamics in Online Auctions.", Journal of Consumer Psychology, forthcoming. Bapna, R., Goes, P., Gupta, A. (2000). "A theoretical and empirical investigation of multi-item online auctions", Information Technology and Management, 1, 1-23.

Bapna, R., Goes, P., Gupta, A. (2003). Analysis and Design of Business-to-Consumer Online Auctions. Management Science, 49(1), 85-101.

Beam, C., Segev, A. (1998). “Auctions on the Internet: A Field Study”, Haas School of Business, University of Californian, Berkeley, Working Paper. 
Belovicz, M.W. (1979), “Sealed-bid auctions: experimental results and applications," in Research in Experimental Economics, V.L. Smith, ed., Greenwich, Conn.: JAI Press.

Carpenter, J., Holmes, J., Hans Matthews, P. (2005). "Charity Auctions: A Field Experiment", Department of Economics, Middlebury College.

Chakravarti, Dipankar, E. Greenleaf, A. Sinha, A. Cheema, J. Cox, D. Friedman, T. Ho, M. Isaac, A. Mitchell, A. Rapoport, M. Rothkopf, J. Srivastava, and R. Zwick (2002), "Auctions: Research Opportunities in Marketing," Marketing Letters, 13(3).

Conlin, M., Gard, L., Hempel, J. (2004). The top givers. Business Week, (29 November 2004): p. 86-90, 92, 94.

Cox, J.C., B. Roberson, and V.L. Smith (1982), "Theory and behavior of single object auctions," in Research in Experimental Economics, V.L. Smith, ed., Greenwich, coon.:JAI Press.

Cox, J.C., B. Roberson, and J.M. Walker (1983), "A test that discriminates between two models of the Dutch-first auction non-isomorphism," Journal of Economic Behavior and Organization, 14:205-219.

Cox, J.C., B. Roberson, and J.M. Walker (1985a), "Expected revenue in discriminative and uniform price sealed bid auctions," in Research in Experimental Economics, V.L. Smith, ed., Greenwich, coon.:JAI Press.

Cox, J.C., B. Roberson, and J.M. Walker (1985b), "Experimental development of sealed-bid auction theory: Calibrating controls for risk aversion," American Economic Review: Papers and Proceedings, 75:160-165.

Engers, M., McManus. (2002). "Charity Auctions”, Department of Economics, University of Virginia, Working Paper.

Forsythe, R., R.m. Isaac, and T.R. Palfrey (1989), "Theories and tests of "blinding bidding" in sealed-bid auctions," Rand Journal of Economics, 20:214-238.

Gilkeson, J.H., Reynolds, K. (2003). "Determinants of Internet Auction Success and Closing

Price: An Exploratory Study" Psychology \& Marketing, 20(6), 537-566.

Goeree, J.K., Maasland, E., Onderstal, S., Turner, J., 2004. "How (not) to

raise money", Department of Economics, University of Virginia Working Paper.

Goeree, J.K., Schram, A., 2003. "Bidding to give: An experimental comparison

of auctions for charity" CREED, University of Amsterdam, Working Paper.

Hansen, R.G. (1985), "Empirical testing of acution theory," American Economic Review, 75:156159.

Hansen, R.G. (1986), "Sealed-bid versus open auctions: The evidence," Economic Inquiry, 24:125-142.

Harrison, G.W. (1989), "Theory and misbehaviour of first-price auctions," American Economic Review, 75:156-159.

Harrison, G.W. (1990), "Risk attitudes in first-price auction experiments: A Bayesian analysis," Review of Economics and Statistics, 72:542-546.

Hou, J., Rego, C. (2003). "A Classification of Online Bidders in a Private Value Auction: Evidence from eBay", in Proceedings of the $6^{\text {th }}$ International Conference on Electronic Commerce Research (ICECR-6), 139-148.

Kagel, J. (1995), "Auctions: A survey of experimental research," in J.J. Kagal and A. Roth (eds), The Handbook of Experimental Economics, 501-86, New Jersey: Princeton University Press.

Kagel, J.H., and D. Levin (1985), "Individual bidder behaviour in first-price private value auctions," Economic Letters, 19:125-128.

Kagal, J.H. and D. Levin (1993), "Independent private value acutions: Bidder behavior in firstsecond- and third-price auctions with varying numbers of bidders," Economic Journal, 103:868879

Klemperer, P. (1999), "Auction theory, A guide to the literature, " Journal of Economic Surveys, 13(3), 227-286. 
Lee, W.S., Partridge, J.E.L., Chua, C. (2003). An Experimental Analysis of First-, Second-, and Third-Price Auctions: The Seller's Perspective. $\mathrm{W}^{5}$ orking Paper.

Lucking-Reiley, D. (1999). "Using Field Experiments to Test Equivalence between Auction Formats: Magic on the Internet", The American Economic Review, 89(5), 1063-1080.

Massad, V.J., Tucker, J.M. (2000). Comparing bidding and pricing between in-person and online auctions. Journal of Product \& Brand Management, 9(5), 325-332).

Meinhard, A.G., Foster, M.K. (2000). "Third sector strategic responses to canada's changing social, political and economic climate: A comparative analysis", Presented at the Fourth International Conference of the International Society for Third Sector Research, Dublin, Ireland Miller, G.J., and C.R. Plott (1985), "Revenue-generating properties of sealed-bid auctions: An experimental analysis of one-rpice and discriminative processes," in Research in Experimental Economics, V.L. Smith, ed., Greenwich, coon.:JAI Press.

Rietz, T.A. (1993), "Implementing and testing risk-preference-induction mechanisms in experimental sealed-bid auction," Journal of Risk and Uncertainty, 7:199-213.

Roth, A.E, Ockenfels, A. (2002). "Last-Minute Bidding and the Rules for Ending Second-Price Auctions: Evidence from eBay and Amazon Auctions on the Internet", The American Economic Review, 92(4), 1093-1103.

Smith, V.L. (1967), "Experimental studies of discrimination versus competition in sealed-bid auction markets," Journal of Business, 40:56-84.

Vickrey, W. (1961), "Counter speculation, acutions and competitive sealed tenders," Journal of Finance 16:8-37.

Wilcox, R.T. (2000). Experts and Amateurs: The Role of Experience in Internet Auctions. Marketing Letters, 11(4), 363-374. 